\title{
Business Activity and its Concentration in the Czech Republic and Poland in the years 2018-2020
}

\author{
Eva HAMPLOVÁ ${ }^{*}$, Beata BAL-DOMAŃSKA² and Kateřina PROVAZNÍKOVÁ1 \\ 1 University of Hradec Králové, Hradec Králove, Czech Republic; eva.hamplova@uhk.cz; \\ katerina.provaznikova@uhk.cz \\ 2 Wroclaw University of Economics and Business, Wroclaw, Poland; Beata.Bal-Domanska@ue.wroc.pl \\ * Corresponding author: eva.hamplova@uhk.cz
}

\begin{abstract}
The paper evaluates the business environment in two economies, by means of the number of actively operating business units in the Czech Republic and Poland in 2018 and 2020. The aim of this article is to assess which regions at the level of Nomenclature of Units for Territorial Statistics show the highest share of active entrepreneurs in terms of the population aged 15-64 in the given region. The subsequent evaluation of business activity over time is especially important. Data from the Czech Statistical Office and Statistics Poland, which are publicly available and can contribute to monitoring the impact of a pandemic crisis on entrepreneurs or the business environment, were used to analyze the concentration of active entrepreneurship. For the regional evaluation of the concentration of business activity, the characteristics of the organized statistical series were used, especially quartiles, and subsequently a map was created in order to visualize the differences in the concentration of business activity at the national and international level. In the Czech Republic, the concentration of entrepreneurs is higher in almost all regions than in Poland, despite the fact that the share of active entrepreneurs in the total number of registered is significantly lower than in Poland.
\end{abstract}

Keywords: business; business environment; national economy

JEL Classification: L25; L26; O10

\section{Introduction}

A regionally balanced business climate is not only a very important issue, but it could even be said to be the primary one, especially in a modern market environment, as it has a significant impact on employment (Thurik et al., 2008), where the business sector has become a key factor, on innovation, the state budget, or, last but not least, on the external economic balance (Stloukalová et al., 2015). The development of the number of statistical units of the enterprise type and their dynamics significantly declare the development of the business sector, the state of the given national economy and, last but not least, regional differences in business at the level of territorial units (Carree, 2015).

Small and medium-sized enterprises, which represent a substantial part of the business sector, have become an increasingly important part of economic development. In this context, it appears that small and medium-sized enterprises can be characterized as the main engine of economic growth. Research has shown that new firms grow faster than established ones 
(Davidsson et al., 2002), thus making a significant contribution to job creation and compensating for job losses in large firms. Therefore, from the point of view of economic policy, it is necessary to know how business activity develops in a given country. This information can help to better target economic policy focused on the support of entrepreneurship (Hamplová \& Kovárník, 2020).

Entrepreneurship is systematically linked to job growth and over time this relationship has intensified (Dvouletý \& Orel, 2020). Entrepreneurship has the greatest impact on the region in which it operates, but it also has positive side-effects on job growth in neighbouring regions (Bal-Domańska, 2018). Entrepreneurship has greater national economic effects in more urbanized regions, where businesses benefit from a condensed market (Henderson \& Weiler, 2010). It is the assessment of the intensity of absorption of business support in the regions that can be a significant factor in their disparities, although this is not clearly proven. Based on the analysis, it was not possible to prove the hypothesis that in the Czech Republic business entities operating in problem regions are preferred when it comes to deciding on the support of projects in the form of subsidies (Felixová, 2012).

\section{Methodology}

The internal database of the Czech Statistical Office obtained from the Register of Economic Entities and of the Statistics Poland was used in the processing of data used in this article. The basic difference between the data publicly available and the data used in this paper is in the concept of the so-called enterprises showing economic activity. According to the Czech Statistical Office, an enterprise showing economic activity is characterized by the fact that in the year of monitoring its activity was identified through the Financial Administration, the Social Security Administration alternatively other administrative sources. According to the Statistics Poland, declared entrepreneurial activity is characterized by the number of entities of the national economy in the REGON register (excluding natural persons running only individual farms). The presented data relate to the so-called active entities, i.e. those that have not reported, for example, the suspension of their activities, are not bankrupt or have not started their activity yet.

Records of the number of enterprises in the years 2018-2020 were obtained through the Information Services Department of the Czech Statistical Office and the Department of Coordination of Business Statistics and business cycle surveys of the Czech Statistical Office and Statistics Poland. The data are organized according to individual regions of the Czech Republic, of which there are 14, and according to individual voivodships of Poland, of which there are 16, and they document the specific number of business entities with identified activity in individual years. Data from the Czech Statistical Office (2020a) and Statistics Poland (2020) for 2020 and 2018 were accepted for the analysis. The basic unit for evaluating the concentration of business activity is the number of active entrepreneurs per 1,000 inhabitants aged 15-64. The number of inhabitants in individual regions was obtained from the data of the Czech Statistical Office (2020b) always as of 1 January of the given period. The characteristics of the ordered statistical series were used for the regional evaluation of the concentration of business activity, especially the quartiles. 


\section{Analysis of Concentration of Active Business Units in the Czech Republic and Poland in 2020-2018}

Four regions in the Czech Republic (Prague, Central Bohemia, South Moravia, MoraviaSilesia) account for more than $50 \%$ of the total number of active businesses in the Czech Republic. In the total number of active business units, enterprises with up to 249 employees represent $99.84 \%$. Representation of active business units has an overwhelming majority in the form of small and medium-sized enterprises (Hamplová \& Kovárník, 2016). According to Statistics Poland (2020) the situation in Poland is similar. From Tab. 1 on the number of registered business entities, it is clear that $46 \%$ of registered entrepreneurs did not report business activity in 2020, which would be recordable through the Financial Administration, the Social Security Administration alternatively other administrative sources. From the point of view of the entire Czech Republic, the share of active business units is $54 \%$ as of 31 December 2020. The share of active business units within the CZ-NUTS 3 regions is shown in Tab. 1. The Karlovy Vary region even has only $51 \%$ of active business units overall registered. A change was recorded in all regions compared to 2018. The number of active entrepreneurs increased in absolute terms in all regions. In the Prague region it was even by $10 \%$. This fact it is also evident from Tab. 1 , where the change is evaluated relatively, i.e. as the ratio of the number of entrepreneurs declaring an activity to the number of entrepreneurs registered. Increased business activity is recorded in 13 regions of the Czech Republic.

Table 1. Number of registered and actually active entrepreneurs by CZ-NUTS 3 and by territorial division as of 31 December 2020, 2018. (Czech Statistical Office, 2020a)

\begin{tabular}{|c|c|c|c|c|c|c|}
\hline $\begin{array}{c}\text { Region } \\
\text { CZ-NUTS } 3\end{array}$ & $\begin{array}{l}\text { Registered } \\
\text { (1) }\end{array}$ & $\begin{array}{c}\text { Declared } \\
\text { activity (2) }\end{array}$ & $\begin{array}{l}\text { Ratio } 2020 \\
(2) /(1)\end{array}$ & Ratio 2018 & $\begin{array}{c}\text { Number of } \\
\text { registered } \\
\text { entrepreneurs } \\
\text { per } 1,000 \\
\text { inhabitants in } \\
\text { age }(15-64)\end{array}$ & $\begin{array}{c}\text { Number of } \\
\text { active } \\
\text { entrepreneurs } \\
\text { per } 1,000 \\
\text { inhabitants in } \\
\text { age }(15-64)\end{array}$ \\
\hline Czech Republic & $2,932,963$ & $1,576,331$ & $54 \% \bowtie$ & $52 \%$ & 428 & 230 \\
\hline Prague & 644,586 & 380,723 & $59 \%$ Љ & $56 \%$ & 748 & 442 \\
\hline Central Bohemian & 351,185 & 194,803 & $55 \%$ 凸 & $54 \%$ & 398 & 221 \\
\hline South Bohemian & 166,853 & 87,012 & $52 \%$ Љ & $51 \%$ & 407 & 212 \\
\hline Plzeň & 147,671 & 73,071 & $49 \%$ & $49 \%$ & 390 & 193 \\
\hline Karlovy Vary & 73,997 & 33,290 & $45 \%$ Љ & $44 \%$ & 390 & 175 \\
\hline Ústí nad Labem & 176,004 & 83,717 & $48 \%$ 凸 & $46 \%$ & 333 & 159 \\
\hline Liberec & 118,076 & 57,144 & $48 \%$ Љ & $47 \%$ & 420 & 203 \\
\hline Hradec Králové & 141,343 & 74,445 & $53 \%$ Љ & $52 \%$ & 408 & 215 \\
\hline Pardubice & 122,901 & 65,585 & $53 \%$ 凸 & $52 \%$ & 368 & 197 \\
\hline Vysočina & 116,360 & 64,919 & $56 \%$ Љ & $55 \%$ & 357 & 199 \\
\hline South Moravian & 326,100 & 175,952 & $54 \%$ Љ & $53 \%$ & 428 & 231 \\
\hline Olomouc & 145,374 & 74,273 & $51 \%$ 凸 & $50 \%$ & 361 & 185 \\
\hline Zlín & 144,213 & 76,050 & $53 \%$ 凸 & $52 \%$ & 387 & 204 \\
\hline Moravian-Silesian & 258,300 & 135,347 & $52 \%$ Љ & $51 \%$ & 333 & 174 \\
\hline
\end{tabular}

The number of active entrepreneurs per 1,000 inhabitants aged 15-64 is a category with which we will continue to work when evaluating the concentration of active business units. From the point of view of regions according to the territorial division of CZ-NUTS 3, the highest concentration can be recorded in the Prague region (442 entrepreneurs per 1,000 
inhabitants aged 14-64), followed by the South Moravian region (231), the Central Bohemian region (221), Hradec Králové region (215), the South Bohemian region (212), Zlín region (203), Liberec region (203). The other half of the group consists of the Vysočina region (199), the Pardubice region (197), the Plzeňský region (193), the Olomouc region (185), the Karlovy Vary region (175), the Moravian-Silesian region (174) and Ústí nad Labem region (158). From the perspective of the CZ-NUTS 3 regions, this region appears to be the region with the lowest number of active business units per 1,000 inhabitants of this region (Fig. 1).

From Tab. 2 on the number of registered business entities, it is clear that $12 \%$ of registered entrepreneurs did not report business activity in 2020. From the point of view of the entire Poland, the share of active business units is $88 \%$ as of 31 December 2020 . The share of active business units within the PL-NUTS 2 regions is shown in Tab. 2.

A change was recorded in all regions compared to 2018. Although the number of active entrepreneurs in all regions increased in absolute terms, a relative decrease was recorded in all voivodships. This fact is also evident from Tab. 2, where the relative change is evaluated, i.e. as the ratio of the number of entrepreneurs declaring activity to the number of registered entrepreneurs.

Table 2. Number of registered and actually active entrepreneurs by PL-NUTS 2 and by territorial division as of 31 December 2020, 2018. (Statistics Poland, 2020)

\begin{tabular}{|c|c|c|c|c|c|c|}
\hline $\begin{array}{c}\text { Region } \\
\text { PL-NUTS } 2\end{array}$ & $\begin{array}{l}\text { Registered } \\
\text { (1) }\end{array}$ & $\begin{array}{c}\text { Declared } \\
\text { activity (2) }\end{array}$ & $\begin{array}{l}\text { Ratio } 2020 \\
(2) /(1)\end{array}$ & $\begin{array}{c}\text { Ratio } \\
2018\end{array}$ & $\begin{array}{c}\text { Number of } \\
\text { registered } \\
\text { entrepreneurs } \\
\text { per } 1,000 \\
\text { inhabitants in } \\
\text { age (15-64) }\end{array}$ & $\begin{array}{l}\text { Number of } \\
\text { active } \\
\text { entrepreneurs } \\
\text { per } 1,000 \\
\text { inhabitants in } \\
\text { age (15-64) }\end{array}$ \\
\hline Poland & $4,663,378$ & $4,103,598$ & $88 \%$ 口 & $90 \%$ & 184 & 161 \\
\hline Dolnośląskie & 396,046 & 348,356 & $88 \%$ 凹 & $90 \%$ & 207 & 182 \\
\hline Kujawsko-pomorskie & 209,750 & 186,604 & $89 \%$ 凹 & $91 \%$ & 152 & 135 \\
\hline Lubelskie & 192,737 & 168,061 & $87 \%$ 凹 & $90 \%$ & 138 & 120 \\
\hline Lubuskie & 120,839 & 106,038 & $88 \%$ 凹 & $90 \%$ & 179 & 157 \\
\hline Łódzkie & 261,498 & 229,999 & $88 \%$ 凹 & $90 \%$ & 164 & 144 \\
\hline Małopolskie & 426,306 & 375,185 & $88 \%$ 凹 & $90 \%$ & 188 & 165 \\
\hline Mazowieckie & 887,329 & 786,938 & $89 \%$ 凹 & $91 \%$ & 251 & 223 \\
\hline Opolskie & 105,694 & 95,009 & $90 \%$ 凹 & $92 \%$ & 160 & 144 \\
\hline Podkarpackie & 188,360 & 165,993 & $88 \%$ 凹 & $90 \%$ & 131 & 115 \\
\hline Podlaskie & 109,492 & 96,962 & $89 \%$ 凹 & $91 \%$ & 138 & 122 \\
\hline Pomorskie & 318,518 & 272,628 & $86 \%$ 凹 & $88 \%$ & 206 & 176 \\
\hline Śląskie & 494,282 & 434,964 & $88 \%$ 凹 & $90 \%$ & 166 & 146 \\
\hline Świętokrzyskie & 120,062 & 105,884 & $88 \%$ 凹 & $90 \%$ & 147 & 130 \\
\hline Warmińsko-mazurskie & 136,403 & 119,390 & $88 \%$ 凹 & $90 \%$ & 142 & 124 \\
\hline Wielkopolskie & 461,225 & 411,684 & $89 \%$ 凹 & $91 \%$ & 199 & 177 \\
\hline Zachodnio-pomorskie & 234,131 & 199,348 & $85 \%$ 凹 & $88 \%$ & 207 & 177 \\
\hline
\end{tabular}

A change was recorded in all regions compared to 2018. Although the number of active entrepreneurs in all regions increased in absolute terms, a relative decrease was recorded in all voivodships. This fact is also evident from Tab. 2, where the relative change is evaluated, i.e. as the ratio of the number of entrepreneurs declaring activity to the number of registered entrepreneurs. 
From the point of view of regions according to the territorial division of PL-NUTS 2, the highest concentration can be recorded in Mazowieckie region (223 entrepreneurs per 1,000 inhabitants aged 15-64), followed by Dolnośląskieregion (182), Wielkopolskie region (177.23), Zachodnio-pomorskieregion (176.58), Pomorskie (176), Małopolskie region (165), Lubuskie region (157), Śląskie region (146). The other half of the group consists of Łódzkieregion (144), Opolskie region (144), Kujawsko-pomorskie region (135), Świętokrzyskie region (130), Warmińsko-mazurskieregion (124), Podlaskieregion (122), Lubelskie region (120) and Podkarpackie (115). From the perspective of the CZ-NUTS 2 regions, this region appears to be the region with the lowest number of active business units per 1,000 inhabitants of this region (Fig 2).

\section{Results and Discussion}

From the information stated above it is evident that the two compared countries under with a very similar 50-year economic history share some clear similarities and, conversely, significant differences can be identified. Both evaluated countries have a very similar organizational structure of their national economy. The vast majority of business entities are included in the category of micro-company (Table 3).

Table 3. Number of actually active entrepreneurs according to the size as of 31 December 2020

\begin{tabular}{|c|r|r|r|r|r|}
\hline \multirow{2}{*}{ Country } & $\begin{array}{c}\text { Declared } \\
\text { activity } \\
\text { TOTAL }\end{array}$ & $\begin{array}{c}\text { Size 0 - 9 } \\
\text { Number of } \\
\text { employees }\end{array}$ & $\begin{array}{c}\text { Size 10 - 49 } \\
\text { Number of } \\
\text { employees }\end{array}$ & $\begin{array}{c}\text { Size 50 - 249 } \\
\text { Number of } \\
\text { employees }\end{array}$ & $\begin{array}{c}\text { Size 250 => } \\
\text { Number of } \\
\text { employees }\end{array}$ \\
\hline Poland & $4,103,598$ & $3,945,983$ & 127,394 & 26,113 & 4,108 \\
& $100 \%$ & $96.2 \%$ & $3.1 \%$ & $0.6 \%$ & $0.1 \%$ \\
\hline Czech Republic & $1,576,331$ & $1,519,429$ & 43,215 & 11,367 & 2,320 \\
& $100 \%$ & $96.4 \%$ & $2.7 \%$ & $0.7 \%$ & $0.1 \%$ \\
\hline
\end{tabular}

More than $2 / 3$ of business units have the form of a natural person without legal subjectivity and $1 / 3$ of entrepreneurs have the form of legal persons (Table 4 ).

Table 4. Number of actually active entrepreneurs according to the legal forms as of 31 December 2020

\begin{tabular}{|l|r|r|r|}
\hline \multicolumn{1}{|c|}{ Country } & $\begin{array}{r}\text { Declared activity } \\
\text { TOTAL }\end{array}$ & Legal persons & $\begin{array}{c}\text { Natural persons } \\
\text { running a business }\end{array}$ \\
\hline Poland & $4,103,598$ & $1,272,464$ & $2,831,134$ \\
& $100 \%$ & $31 \%$ & $69 \%$ \\
\hline Czech Republic & $1,576,331$ & 458,475 & $1,117,856$ \\
& $100 \%$ & $29 \%$ & $71 \%$ \\
\hline
\end{tabular}

Both countries are assessed almost identically according to the Doing Business study (World Bank, 2020). The study has compared business rules and regulations that characterize the business environment for 17 years.

However, the analysis shows a completely different intensity of specific entrepreneurs' involvement in the active business of a particular country. While in the Czech Republic an entrepreneur registers either as a natural person or a legal entity for the purpose of entrepreneurial activity, subsequently this activity is actually actively performed by every other entrepreneur. We can explain this fact mainly due to the very high involvement of 
natural persons in business. These people have the business as a secondary form of income. In other words, they have a job and are employees and earn extra money from the business. The situation is completely different in the case of Poland. Although natural persons running only individual farms are not included in the number of business entities, approximately every 10 registered entrepreneurs will not participate in active business.

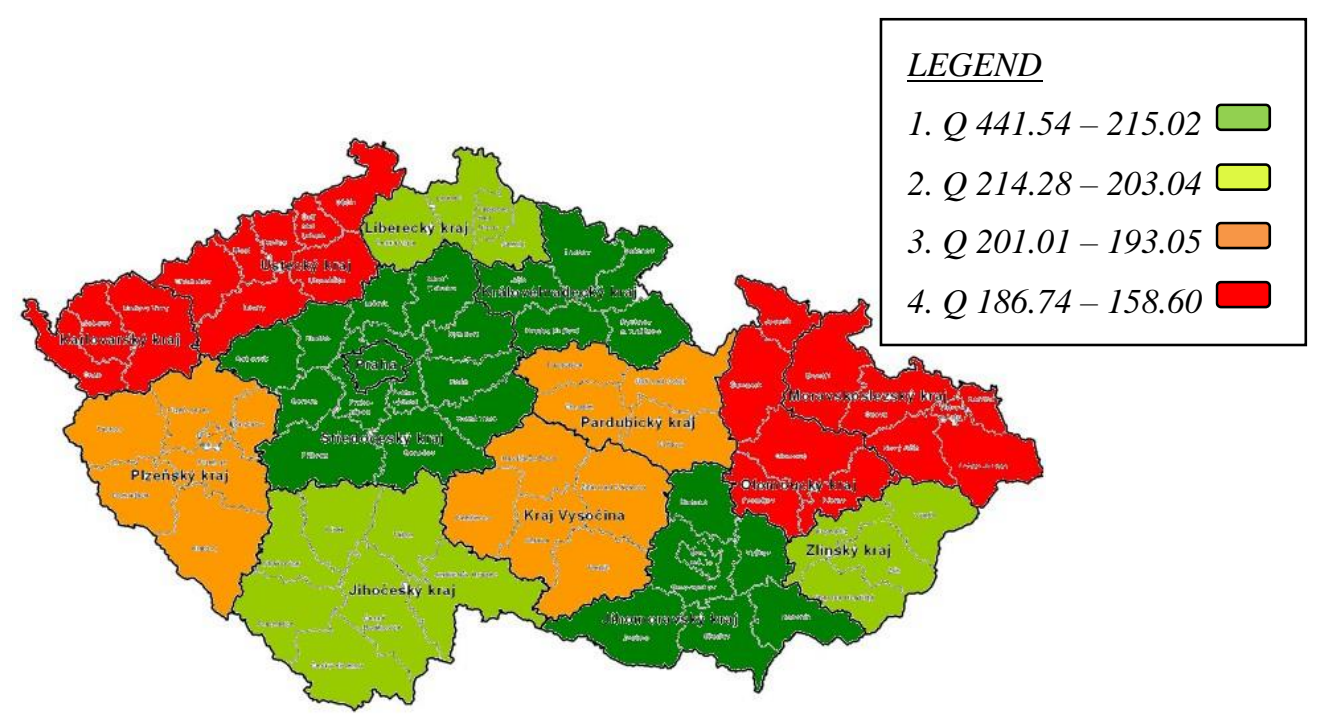

Figure 1. Number of entrepreneurs in regions of the Czech Republic per 1,000 inhabitants aged 15-64 as of 31 December 2020

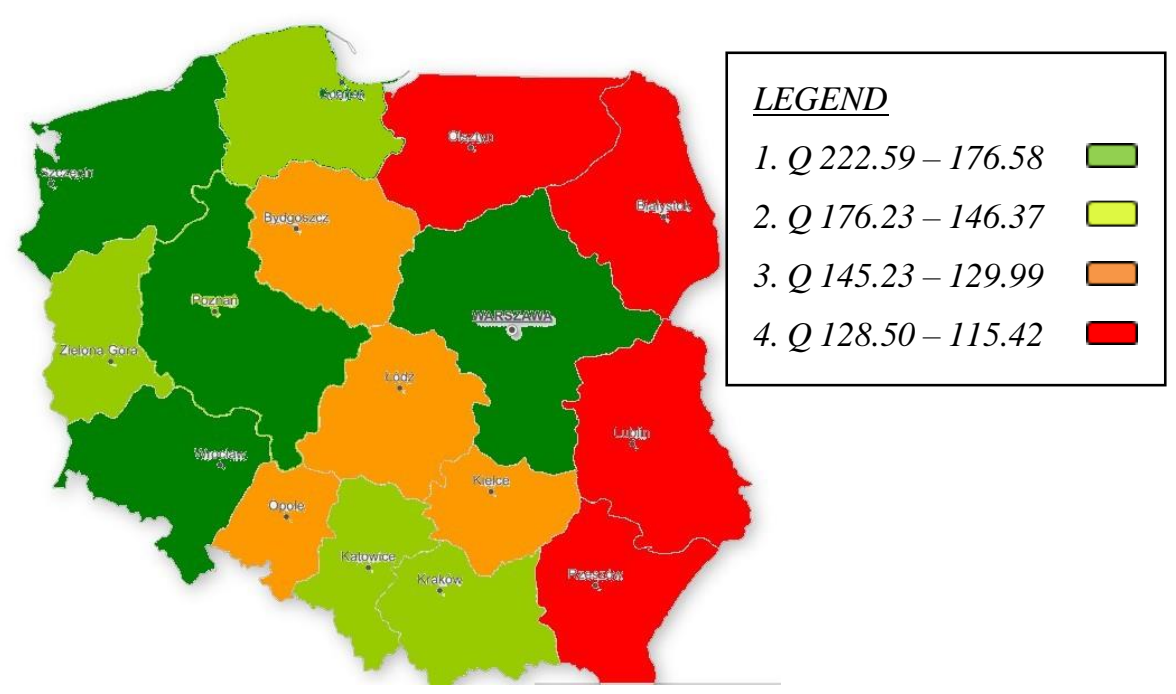

Figure 2. Number of entrepreneurs in voivodships of Poland per 1,000 inhabitants aged $15-64$ as of 31 December 2020

\section{Conclusions}

This paper focused on the evaluation of the current situation of business activity in the Czech Republic and Poland. The aim was to map the extent of the involvement of entrepreneurs in individual countries and also in individual regions (voivodships), to visualize the differences at the national and international level. In the Czech Republic, the 
share of active entrepreneurs is very low due to the number of registered entrepreneurs (54\%), but compared to 2018 , this involvement is $2 \%$ higher. In 2020 , absolutely and relatively more entrepreneurs joined the business than in 2018. It follows from the above that the COVID 19 crisis has paradoxically increased business activity in the Czech Republic. Unfortunately, it cannot be ruled out that the motive for the increased activity was the widespread use of state aid in connection with government regulations restricting business activity during the COVID 19 pandemic. In Poland, the situation developed differently. The absolute number of registered entrepreneurs increased, but the relative number decreased by $2 \%$. Relatively fewer entities declared business activity at the time of the 2020 crisis than in 2018. It was here that a problem related to the limitation of business activity may have arisen in 2020, which we cannot confirm due to the low detail of the analyzed data. When comparing entrepreneurial activity, which was evaluated in this paper on the basis of the number of activities of declaring entrepreneurs per 1,000 people aged 15-64, the concentration of these entrepreneurs is significantly higher in the Czech Republic and in almost all its regions than in Poland.

Acknowledgments: This research was funded by Specific research grant 2021 Economic Impacts under the Industry 4.0/Society 5.0 Concept at the Faculty of Informatics and Management of the University of Hradec Kralove, Czech Republic. It was prepared in cooperation with students of Ph.D. study at Department of Economics, namely with Ing. Lucie Novotná and Ing. Martin Král.

\section{References}

Bal-Domańska, B. (2018). The Socio-economic Dimension of Industry in Subregions. Argumenta Oeconomica Cracoviensia, 19, 133-152. https://doi.org/10.15678/AOC.2018.1907

Carree, M., Congregado, E., Golpe, A., \& van Stel, A. (2015). Self-employment and job generation in metropolitan areas, 1969-2009. Entrepreneurship \& Regional Development, 27(3-4), 181-201. https://doi.org/10.1080/08985626.2015.1025860

Czech Statistical Office. (2020a). Births and deaths of businesses [Data set]. Database of the Statistical Business Register. Not public, internal document.

Czech Statistical Office. (2020b). Population of territorial units of the Czech Republic, 1 January 2020. [Data set]. Retrieved December 12, 2020 from. https://www.czso.cz/csu/czso/population-of-municipalities-1-january-2020

Davidsson, P., Kirchhoff, B., Hatemi-J, A., \& Gustavsson, H. (2002). Empirical Analysis of Business Growth Factors Using Swedish Data. Journal of Small Business Management, 40(4), 332-349. https://doi.org/10.1111/1540-627X.00061

Dvouletý, O., \& Orel, M. (2020). Individual determinants of entrepreneurship in Visegrád countries: Reflection on GEM data from the Czech Republic, Hungary, Poland, and Slovakia. Entrepreneurial Business and Economics Review, 8(4), 123-137. https://doi.org/10.15678/EBER.2020.080407

Felixova, K. (2012). Evaluation of the absorption intensity of the entrepreneurial support in the regions funded intensely by the government. E+M: Ekonomie a Management, 15(1), 17-27.

Hamplová, E., \& Kovárník, J. (2020). Globalization and Entrepreneurship: Selected Topics in Visegrad Four Countries. SHS Web of Conferences, 74, 05009. https://doi.org/10.1051/shsconf/20207405009

Hamplová, E., \& Kovárník, J. (2016). Analýza vývoje počtu podnikatelských jednotek v České republice v letech 2008-2014. In 19th International Colloquium on Regional Sciences. Conference Proceedings (pp. 226-232). https://doi.org/10.5817/CZ.MUNI.P210-8273-2016-28

Henderson, J., \& Weiler, S. (2010). Entrepreneurs and Job Growth: Probing the Boundaries of Time and Space. Economic Development Quarterly, 24(1), 23-32. https://doi.org/10.1177/0891242409350917

Statistics Poland. (2020). Kwartalna informacja o podmiotach gospodarki narodowej w rejestrze REGON rok 2020 [Data set]. Retrieved January 31, 2020, from https://stat.gov.pl/obszary-tematyczne/podmioty-gospodarczewyniki-finansowe/zmiany-strukturalne-grup-podmiotow/kwartalna-informacja-o-podmiotachgospodarki-narodowej-w-rejestrze-regon-rok-2020,7,8.html 
Stloukalová, T., Jurčík, R., \& Srdošová, K. (2015). Malé a střední podniky ve veřejných zakázkách krajů v České republice. In 18th International Colloquium on Regional Sciences. Conference Proceedings (pp. 143-147). https://doi.org/10.5817/CZ.MUNI.P210-7861-2015-18

Thurik, A. R., Carree, M. A., van Stel, A., \& Audretsch, D. B. (2008). Does self-employment reduce unemployment? Journal of Business Venturing, 23(6), 673-686. https://doi.org/10.1016/j.jbusvent.2008.01.007

World Bank. (2020). Doing business 2020: Comparing business regulation in 190 economies. The World Bank. 